\title{
METODA OBLICZEŃ AERODYNAMICZNYCH SAMOLOTU PASAŻERSKIEGO PODCZAS LOTU W FORMACJI
}

\author{
Adam Antczak, Krzysztof Sibilski \\ Politechnika Warszawska, Wydziat Mechaniczny Energetyki i Lotnictwa, Warszawa \\ e-mail: aantczak@meil.pw.edu.pl; krzysztof.sibilski@pw.edu.pl
}

\begin{abstract}
W artykule wyznaczono obciążenia aerodynamiczne metodą pasową dla samolotu skrzydłowego lecącego w formacji $\mathrm{V}$. We wstępie przedstawiona została potrzeba linii lotniczych na oszczędności paliwowe wraz z przykładowymi ich metodami. Kolejno przedstawiona została analiza możliwości wykorzystania lotu w formacji w samolotach pasażerskich. Następnie pokazany został model matematyczny wyznaczania prędkości indukowanej wygenerowanej przez samolot lidera skrzydłowego oraz opisana została metoda pasowa do wyznaczenia obciążeń aerodynamicznych. Na końcu przedstawione zostały założenia obliczeniowe oraz wyniki dokonanych obliczeń.
\end{abstract}

Stowa kluczowe: loty formacyjne, linia lotnicza, aerodynamika, metoda pasowa

\section{Linia lotnicza}

Rosnące koszty paliw, pracy ludzkiej, części lotniczych mogłyby negatywnie wpływać albo na jakość oferowanych usług przez linie lotnicze, albo na wzrost cen biletów. Jednakże wszyscy operatorzy lotniczy poszukują oszczędności w innych aspektach swoich działalności. Celem ograniczenia wydatków na obsługę oraz na części zamienne wymieniają flotę samolotów na młodszą. Optymalizuje się siatki połączeń, by czas pobytu samolotu na ziemi skrócić do minimum. Zakupuje się specjalistyczne oprogramowanie przyspieszające pracę agentów handlingowych czy dyspozytorów lotniczych.

Analogicznie do podróży samochodem, samolot przed rozpoczęciem lotu należy zatankować. Przykładowo, samolot Boeing $767 \mathrm{w}$ jeden rejs zabiera 60 ton paliwa [1], a cena za tonę wynosi około 800 amerykańskich dolarów, daje to około 48 tys. dolarów.

Wymiana floty w przypadku PLL LOT z samolotu Boeing 767 na typ 787 pozwoliła zaoszczędzić $20 \%$ paliwa na jednym locie [2].

Organizacja Międzynarodowego Lotnictwa Cywilnego (ICAO) w ramach rekomendacji poleca wszystkim operatorom tworzenie własnej polityki oszczędności paliwowych [3]. Jedną z rekomendacji jest chociażby regularne mycie płatowca. Osadzający się brud powoduje wzrost siły oporu, a zatem niezbędnego ciągu silników do lotu.

Każda z linii lotniczych poszukuje własnych unikalnych rozwiązań pozwalających znajdować się cały czas o krok naprzód od konkurencji.

\section{Lot $\mathrm{w}$ formacji}

Poszukując możliwych oszczędności, należy również spojrzeć na świat zwierząt. Ciekawym zjawiskiem w okresach migracyjnych są klucze ptaków lecących po niebie. Dzięki rozwojowi technologii udało się zbadać [4], że ptaki lecacce w kluczu mogą wykonać o $71 \%$ dłuższy lot niż w przypadku lotu pojedynczego ptaka. Stwierdzono również, że taka sytuacja ma miejsce dzięki wpływowi cyrkulacji generowanej przez wiry zaskrzydłowe lidera na skrzydłowego. 


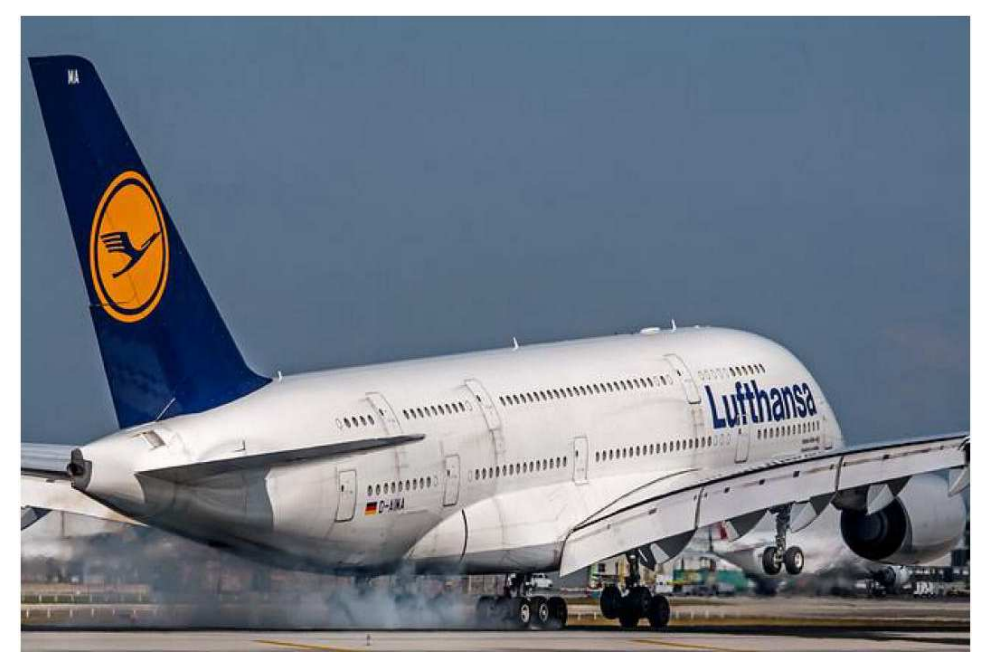

Rys. 1. Brudny Airbus 380 (https://www.airliners.net/forum/viewtopic.php?t=580467)

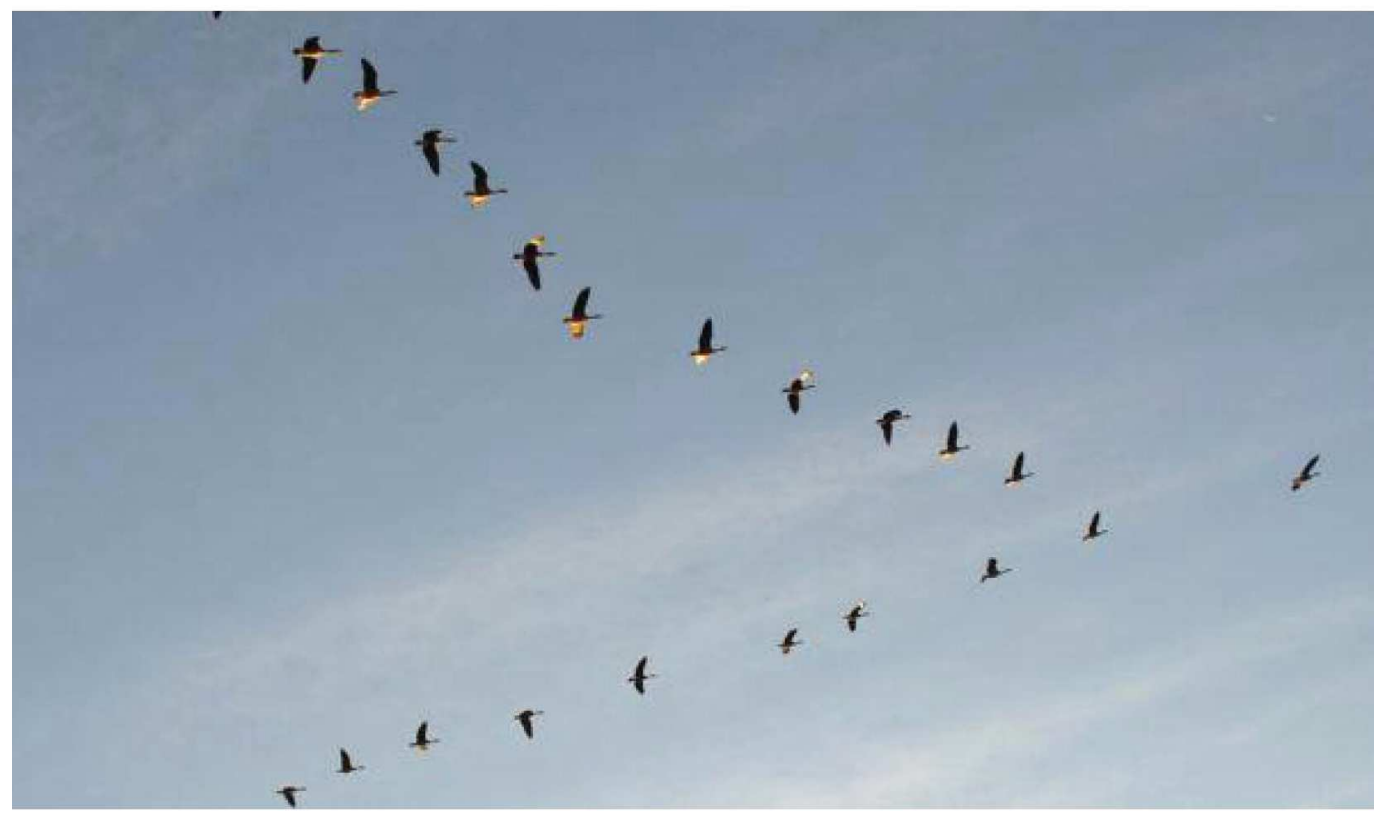

Rys. 2. Ibisy grzywiaste w kluczu [5]

Dużym krokiem naprzód w rozwoju badań nad możliwością wdrożenia lotów w formacji w statkach powietrznych była analiza wykonana przez Boeinga wraz z firmą transportową FedEx w 2009 roku, w której przeprowadzono optymalizację połączeń lotniczych ich samolotów pomiędzy bazami w Stanach Zjednoczonych [6]. Pokazano wtedy, że lot w formacji pozwoliłby zaoszczędzić $12,46 \%$ paliwa dla przelotu formacji złożonej z trzech samolotów oraz 7,85\% dla dwóch samolotów. Dla połączeń wykonywanych codziennie przez cały rok jest to oszczędność 2,8 mln dolarów oraz 700 tys. galonów paliwa, co również jest aspektem proekologicznym.

Wspólna praca zaowocowała utworzeniem realnej operacji lotniczej w 2018 roku. Wykonali oni przelot dwóch samolotów Boeing 777 przy separacji podłużnej czterech tysięcy stóp [7] i normalnej prędkości przelotowej. Wynikiem tego lotu była $5 \%$ oszczędność na paliwie dla samolotów skrzydłowych. 


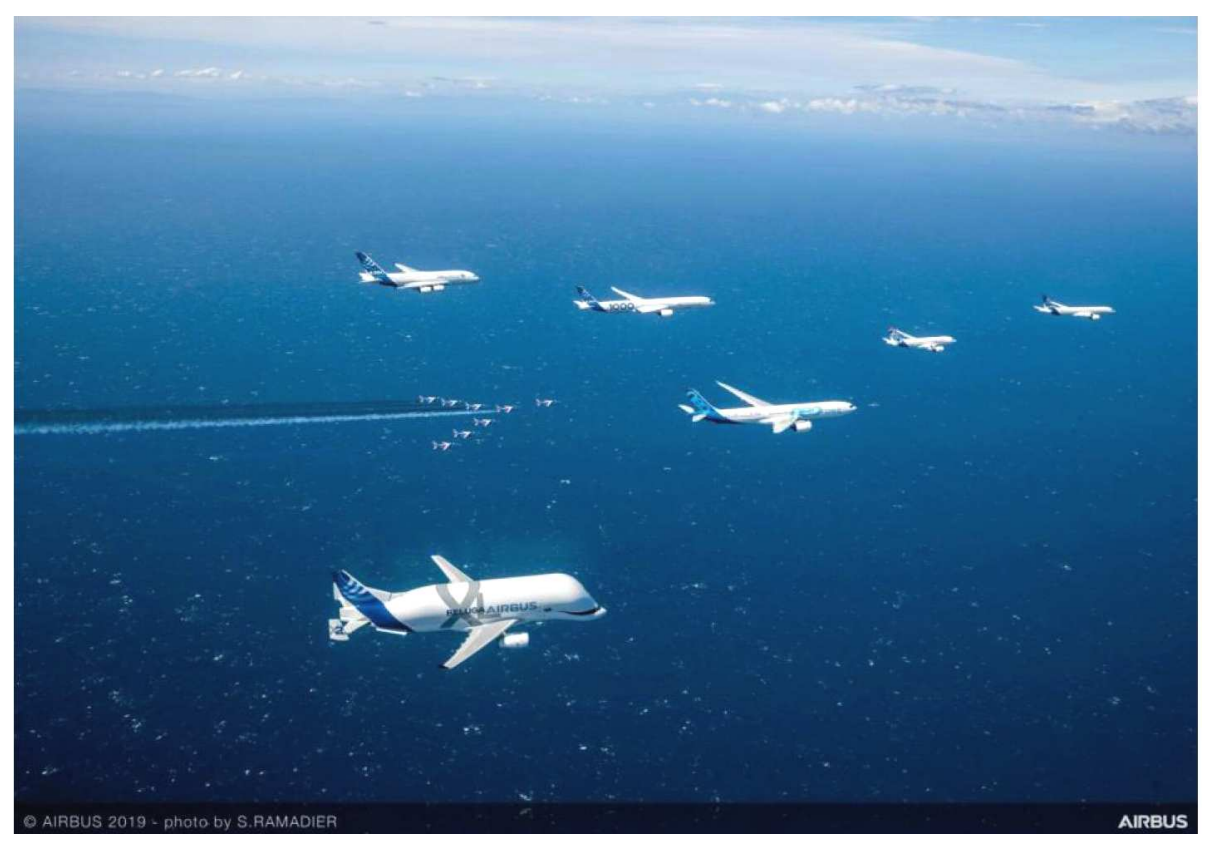

Rys. 3. Formacja stworzona przez Airbusa (https://theaviationgeekclub.com/here-are-some-cool-photosof-the-formation-flight-celebrating-airbus-50th-anniversary/)

\section{Wiry zaskrzydłowe}

Dla samolotu wlot w wiry zaskrzydłowe wygenerowane przez inny statek powietrzny może stanowić zagrożenie dla jego dalszego lotu. Przykładem może być katastrofa samolotu rządowego Learjet $45 \mathrm{w}$ Meksyku w dniu 4 listopada 2008 roku. Pomimo przepisów, które określały minimalną separację podłużną dla lądujących samolotów na $5 \mathrm{NM}$, zbliżył się on na odległość 4,1 NM od lecącego przed nim samolotu Boeing 767-300ER. Piloci nie byli w stanie przeciwdziałać powstałym obciążeniom, co doprowadziło do katastrofy [8].

W locie w formacji istotnym aspektem jest ustawienie w takim położeniu samolotów względem siebie, aby nie było to niebezpieczne, a pozwalało zmniejszać opór samolotu skrzydłowego.

Pełne wyprowadzenie wpływu wirów generowanych przez lidera na samolot skrzydłowy zostało przedstawione w publikacji w 2018 roku [9].

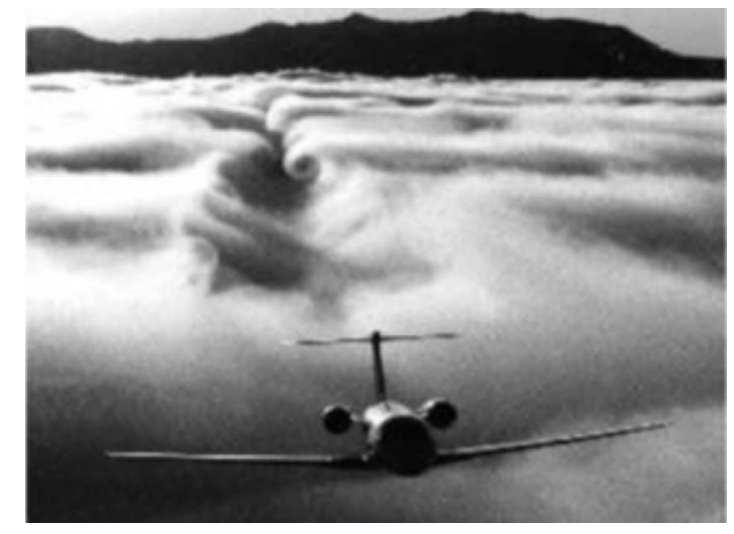

Rys. 4. Ślad wirowy za samolotem [10]

W śladzie wirowym powstaje prędkość indukowana o składowej w każdej osi. Pionowa składowa prędkości indukowanej generuje dodatkowy kąta natarcia samolotu względem pierwotnego 
kąta natarcia lotu. Taki powstały kąt nazywany jest kątem indukowanym, wyliczanym z następującego równania

$$
\alpha_{i}=\frac{w}{V}
$$

gdzie: $w$ - pionowa składowa prędkości indukowanej $[\mathrm{m} / \mathrm{s}], V$ - prędkość lotu $[\mathrm{m} / \mathrm{s}]$.

Powstały kąt indukowany powoduje wytworzenie dodatkowej składowej siły nośnej $L^{\prime}$, działającej w kierunku podłużnym samolotu, wyznaczanej z wzoru

$$
L^{\prime}=L \operatorname{tg} \alpha_{i}
$$

W zwykłym locie ustalonym ciąg silników równoważy siłę oporu lecącego samolotu. Wygenerowana składowa siły nośnej powiększa wartość siły pchającej statek powietrzny

$$
T=D-\Delta L
$$

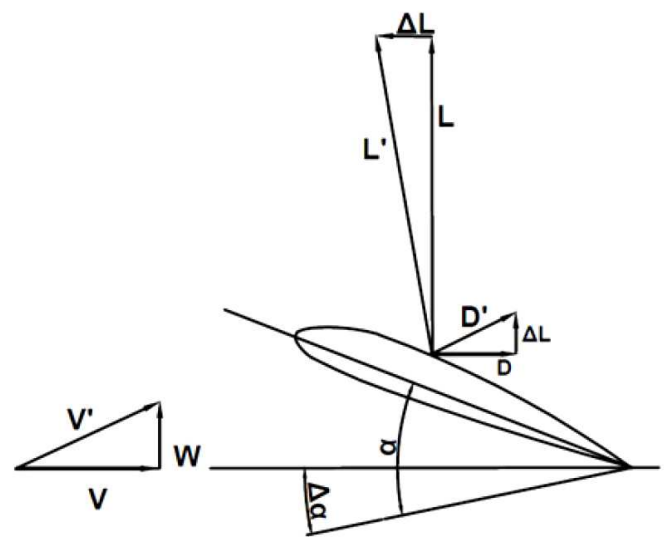

Rys. 5. Rozkład sił z uwzględnieniem prędkości indukowanej [9]

\section{Metoda pasowa - wstęp}

Wir generowany przez samolot lidera wpływa również na powstanie prędkości kątowych przechylania, pochylania i odchylania $(P, Q, R)$ na samolocie skrzydłowym. Powodują one utworzenie dodatkowych obciążeń aerodynamicznych na jego skrzydłach. Jednym z zadań przy analizie możliwości wykorzystania lotów w formacji w normalnych operacjach lotniczych jest sprawdzenie wpływu ww. obciążeń na samolot skrzydłowy. Przelot samolotów w formacji ma odbywać się jako lot ustabilizowany, o stałych parametrach lotu. Wymaga to, by samolot skrzydłowy był w stanie przeciwdziałać wszystkim negatywnym wpływom samolotu lidera. Do tego celu wykorzystana została metoda pasowa, która pozwala w prosty sposób na uwzględnienie prędkości indukowanej generowanej przez wir.

Kolejność obliczeń metody pasowej była następująca [11]:

1) podział skrzydeł oraz usterzenia poziomego na szereg elementów (pasów),

2) w każdym pasie został wyznaczony lokalny kąt natarcia i kąt ślizgu oraz wartość wypadkowego wektora prędkości (do wyliczenia brana była pod uwagę prędkość indukowana generowana przez lidera oraz wpływ wirów generowanych przez sąsiednie pasy),

3) z charakterystyk aerodynamicznych profilu wyznaczany był lokalny współczynnik aerodynamiczny siły nośnej, oporu oraz momentu pochylającego. 


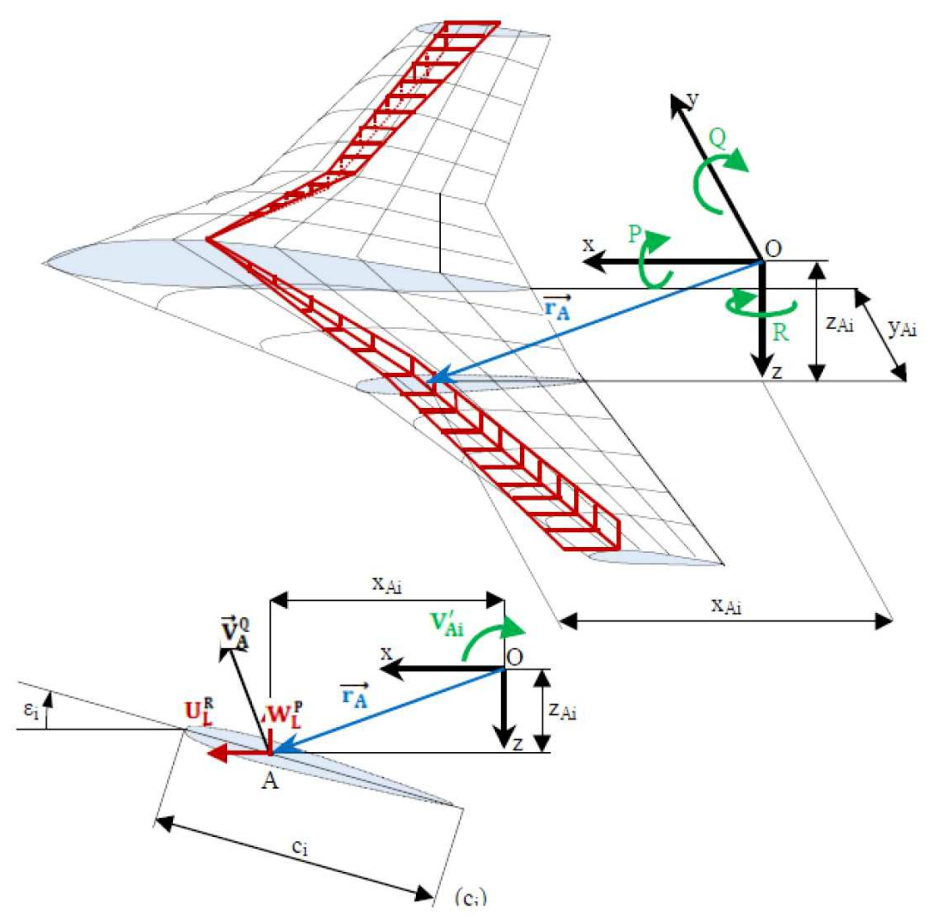

Rys. 6. Rozkład prędkości powstały na skutek prędkości kątowej $P, Q$ i $R$ [12]

\section{Metoda pasowa - model}

Wpływ wirów z pasów sąsiadujących wyznaczany jest w podobny sposób co wpływ lotu lidera na samolot skrzydłowy. Na sąsiadujących pasach powstają wiry, ich mierzalną wartością jest cyrkulacja, która posłuży do wyznaczenia prędkości indukowanej.

Na podzielonym na panele płacie rozmieszczane są wektory wirowości przedstawione na rysunkach 7 i 8 i ich punkty zaczepienia:

- 1, 2, 3, 4 - są to punkty zaczepienia wektorów cyrkulacji na danym pasie.

Punkty 1 i 2 leżą na płacie w odległości 1/4 lokalnej cięciwy od krawędzi natarcia. Punkty 3 i 4 znajdują się w dużej odległości za płatem, w przybliżeniu 10-krotności cięciwy skrzydła. Wektory leżące pomiędzy punktami 1, 4 oraz 2, 3 są równoległe do wypadkowego wektora lokalnej prędkości.

- $k$ - punkt kontrolny, w którym wyznaczana jest prędkość indukowana na danym pasie.

Jeżeli oznaczymy wektor współczynników wpływu jako A, to przykładowo

$$
\mathbf{A}_{12}=\frac{\mathbf{r}_{1 k} \times \mathbf{r}_{2 k}}{\left|\mathbf{r}_{1 k} \times \mathbf{r}_{2 k}\right|^{2}} \mathbf{r}_{12}\left(\frac{\mathbf{r}_{1 k}}{r_{1 k}-\mathbf{r}_{2 k}} r_{2 k}\right)
$$

gdzie: $\mathbf{r}_{1 k}$-wektor pomiędzy punktami 1 i $k, \mathbf{r}_{2 k}$-wektor pomiędzy punktami 2 i $k, \mathbf{r}_{12}$-wektor pomiędzy punktami 1 i 2.

Wpływ wektorów cyrkulacji na konkretnym panelu na prędkość indukowaną w jego punkcie $k$ można przedstawić jako

$$
\mathbf{V}_{i n d}=\frac{\Gamma}{4 \pi}\left(\mathbf{A}_{12}+\mathbf{A}_{23}+\mathbf{A}_{34}+\mathbf{A}_{41}\right)
$$

Do powyższego równania należy wstawić poniższą zależność na cyrkulację

$$
\Gamma_{i}=\frac{1}{2} U C z_{i} c_{i} \frac{y}{b}
$$




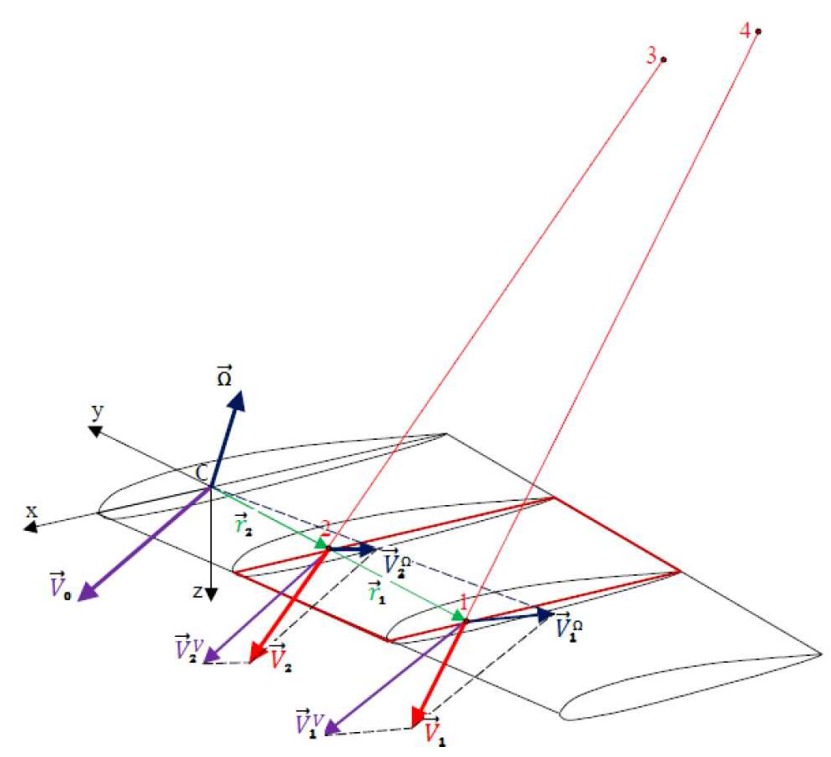

Rys. 7. Rozmieszczenie punktów 1, 2, 3 i 4 na pasie [12]

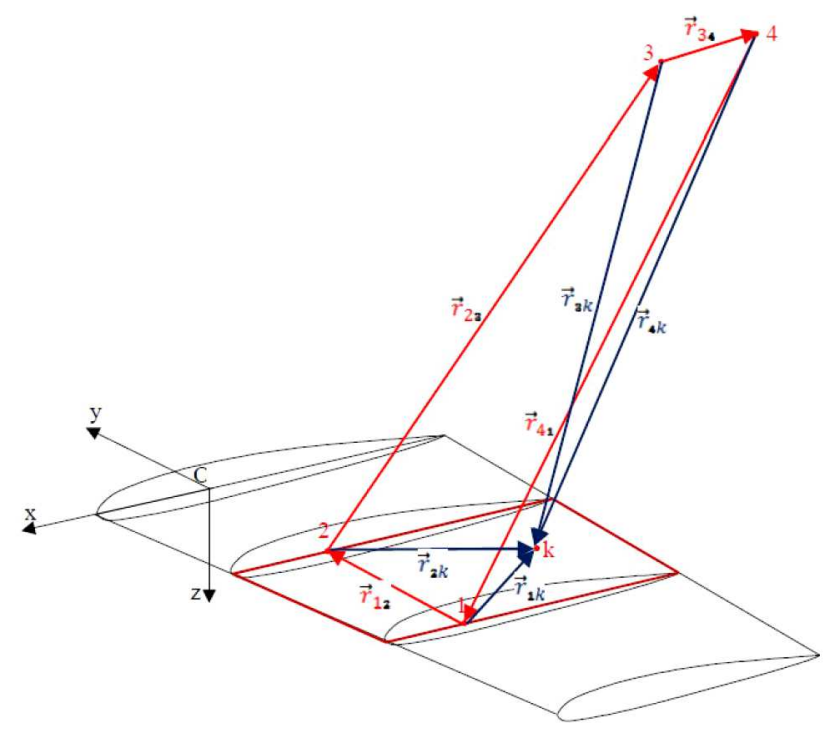

Rys. 8. Rozmieszczenie wektorów na pasie [12]

gdzie: $U$ - prędkość przepływu niezaburzonego, $C z_{i}$ - lokalny bezwymiarowy współczynnik siły nośnej profilu, $c_{i}$ - lokalna cięciwa, $y$ - grubość panelu, $b$ - rozpiętość płatowca.

W celu wyznaczenia trzech składowych zostało wykorzystane poniższe przekształcenie wzoru $(5.2)$

$$
u=K A_{x} \quad v=K A_{y} \quad w=K A_{z}
$$

gdzie

$$
K=\frac{\Gamma_{i}}{4 \pi}\left[\frac{1}{\left|\mathbf{r}_{1} \times \mathbf{r}_{2}\right|^{2}}\left(\frac{\mathbf{r}_{k} \mathbf{r}_{1}}{r_{1}}-\frac{\mathbf{r}_{k} \mathbf{r}_{2}}{r_{2}}\right)+\frac{1}{\left|\mathbf{r}_{2} \times \mathbf{r}_{3}\right|^{2}}\left(\frac{\mathbf{r}_{k} \mathbf{r}_{2}}{r_{2}}-\frac{\mathbf{r}_{k} \mathbf{r}_{3}}{r_{3}}\right)+\cdots\right]
$$

Prędkość kątowa $\Omega$ powoduje powstanie zmiennych rozkładów prędkości na skrzydle samolotu. Przykładowy rozkład prędkości wzdłuż cięciwy na dowolnym przekroju skrzydła, przy działaniu prędkości pochylania $Q$, przedstawiono na rys. 9. 


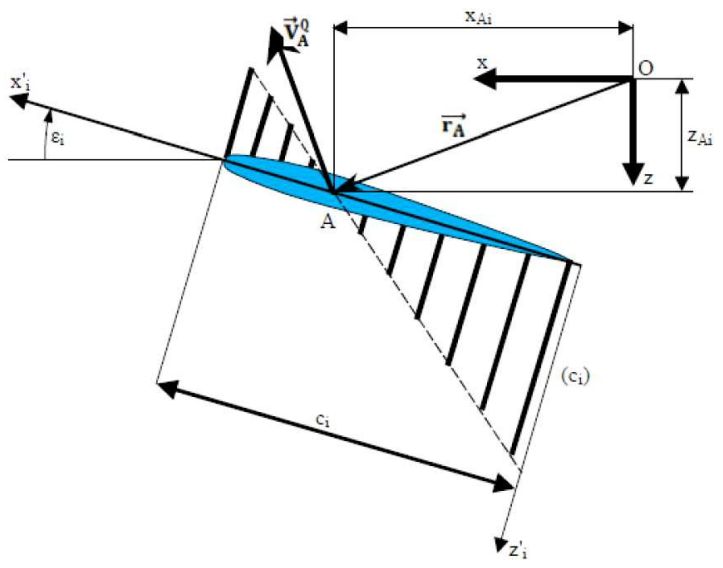

Rys. 9. Rozkład prędkości wzdłuż cięciwy na skutek wystąpienia prędkości kątowej pochylania $Q$ [12]; $A$ - punkt leżący w 1/4 lokalnej cięciwy, $c_{i}$ - lokalna cięciwa, $\varepsilon_{i}$ - kąt nachylenia lokalnego układu współrzędnych względem układu samolotowego (dla skrzydła - kąt zwichrzenia geometrycznego), $x_{A i}, z_{A i}$ - współrzędne punktu $A \mathrm{w}$ układzie samolotowym, $\overrightarrow{\mathbf{V}}_{A}^{Q}$ - wypadkowa prędkość punktu $A$

Wystąpienie prędkości pochylania skutkuje powstaniem zmiennego rozkładu prędkości $W_{A}^{\prime}$ wzdłuż lokalnej cięciwy. Średnia wartość powyższej prędkości wynosi

$$
W_{A}^{\prime}=\frac{1}{c_{i}} \int_{-\frac{1}{4} c_{i}}^{\frac{3}{4} c_{i}} Q x_{i} d x=\frac{1}{4} Q c_{i}
$$

Prędkości kątowe $P$ i $R$ powodują, poza wygenerowaniem zmiennego rozkładu prędkości liniowej wzdłuż lokalnej cięciwy, powstanie zmiennego rozkładu prędkości liniowej wzdłuż rozpiętości całego skrzydła, rys. 6. Przy uwzględnieniu nachyleniu lokalnej cięciwy względem osi układu samolotowego otrzymujemy

$$
V_{A}^{\prime}=\frac{1}{4} \int_{-\frac{1}{4} c_{i}}^{\frac{3}{4} c_{i}}\left(P \sin \varepsilon_{i}+R \cos \varepsilon_{i} x_{i}\right) d x=\frac{1}{4}\left(P \sin \varepsilon_{i}+R \cos \varepsilon_{i}\right) c_{i}
$$

Ogólna postać wektora prędkości punktu $A$, leżącego w 1/4 lokalnej cięciwy, powstałego przez prędkość kątową $\omega$ ma postać

$$
\begin{aligned}
\mathbf{V}_{A}^{\Omega} & =\boldsymbol{\Omega} \times \mathbf{r}_{A} \\
\mathbf{V}_{A}^{\Omega} & =\left[\begin{array}{ccc}
i & j & k \\
P & Q & R \\
x_{A} & y_{A} & z_{A}
\end{array}\right]=\left[\begin{array}{c}
Q z_{A}-R y_{A} \\
R x_{A}-z_{A} \\
P y_{A}-Q x_{A}
\end{array}\right]
\end{aligned}
$$

Następnie powyższy wektor prędkości należy przetransformować z układu samolotowego $O x y z$ do układu lokalnego $O x_{i}^{\prime} y_{i}^{\prime} z_{i}^{\prime}$ odchylonego o kąt $\varepsilon$ przy użyciu poniższej macierzy transformacji $\mathbf{T}$

$$
\mathbf{T}=\left[\begin{array}{ccc}
\cos \varepsilon & 0 & -\sin \varepsilon \\
0 & 1 & 0 \\
\sin \varepsilon & 0 & \cos \varepsilon
\end{array}\right]
$$


Jak również należy zsumować ze średnimi wartościami prędkości $W_{A}^{\prime}$ oraz $V_{A}^{\prime}$ wyznaczonymi wcześniej, po czym otrzymujemy

$$
\begin{aligned}
& U_{i}^{\Omega}=\left(Q z_{A}-R y_{A}\right) \cos \varepsilon_{i}-\left(P y_{A}-Q x_{A}\right) \sin \varepsilon_{i} \\
& V_{i}^{\Omega}=R x_{A}-P z_{A}+\frac{1}{4}\left(P \sin \varepsilon_{i}+R \cos \varepsilon_{i}\right) c_{i} \\
& W_{i}^{\Omega}=\left(Q z_{A}-R y_{A}\right) \sin \varepsilon_{i}+\left(P y_{A}-Q x_{A}\right) \cos \varepsilon_{i}+\frac{1}{4} Q c_{i}
\end{aligned}
$$

Natomiast składowe prędkości lotu samolotu po transformacji o macierz $\mathbf{T}$ do układu lokalnego przyjmują postać

$$
\left[\begin{array}{c}
U_{i}^{\prime V} \\
V_{i}^{\prime V} \\
W_{i}^{\prime V}
\end{array}\right]=\left[\begin{array}{c}
U \cos \varepsilon-W \sin \varepsilon \\
V \\
U \sin \varepsilon+W \cos \varepsilon
\end{array}\right]
$$

Po zsumowaniu wszystkich prędkości liniowych w układzie lokalnym otrzymujemy następujące całkowite wartości prędkości liniowych

$$
\left[\begin{array}{c}
U_{i}^{\prime} \\
V_{i}^{\prime} \\
W_{i}^{\prime}
\end{array}\right]=\left[\begin{array}{c}
U_{i}^{\prime V}+U_{i}^{\Omega}+U_{i}^{L}+U_{i}^{P} \\
V_{i}^{\prime V}+V_{i}^{\Omega}+V_{i}^{L}+V_{i}^{P} \\
W_{i}^{\prime V}+W_{i}^{\Omega}+W_{i}^{L}+W_{i}^{p}
\end{array}\right]
$$

gdzie: $U_{i}^{L}, V_{i}^{L}, W_{i}^{L}$ - składowe prędkości wygenerowane przez samolot lidera, $U_{i}^{p}, V_{i}^{p}, W_{i}^{p}$ - składowe prędkości wygenerowane przez poboczne pasy.

Następnie wyliczany jest lokalny kąt natarcia $\alpha_{i}$

$$
\alpha_{i}=\operatorname{tg}^{-1} \frac{W_{i}^{\prime}}{U_{i}^{\prime}}
$$

oraz kąt ślizgu $\beta_{i}$

$$
\beta_{i}=\sin ^{-1} \frac{V_{i}^{\prime}}{\sqrt{\left(U_{i}^{\prime}\right)^{2}+\left(W_{i}^{\prime}\right)^{2}}}
$$

W ten sam sposób wyznaczane są kąty opływu zależne od prędkości liniowej

$$
\alpha_{i}^{V}=\operatorname{tg}^{-1} \frac{W_{i}^{\prime V}}{U_{i}^{\prime V}} \quad \beta_{i}^{V}=\sin ^{-1} \frac{V_{i}^{\prime V}}{\sqrt{\left(U_{i}^{\prime V}\right)^{2}+\left(W_{i}^{\prime V}\right)^{2}}}
$$

Zmiana kątów opływu powoduje zmianę kierunku działania sił i momentów sił aerodynamicznych.

Całkowity wpływ prędkości kątowej na obciążenie skrzydła przedstawiamy jako różnice pomiędzy całkowitym obciążeniem od wszystkich składowych prędkości a obciążeniem od prędkości liniowej.

Lokalna zmiana sił w układzie samolotowym przedstawiona zostaje jako

$$
\begin{gathered}
{\left[\begin{array}{c}
X_{\Omega i}^{a} \\
Y_{\Omega i}^{a} \\
Z_{\Omega i}^{a}
\end{array}\right]=\frac{1}{2} \rho S V_{0 i}^{2}\left[\begin{array}{ccc}
-\cos \alpha_{i} \cos \beta_{i} & -\cos \alpha_{i} \sin \beta_{i} & \sin \alpha_{i} \\
-\sin \beta_{i} & \cos \beta_{i} & 0 \\
-\sin \alpha_{i} \cos \beta_{i} & -\sin \alpha_{i} \sin \beta_{i} & -\cos \alpha_{i}
\end{array}\right]\left[\begin{array}{c}
C x_{i}\left(\alpha_{i}, \beta_{i}, M_{a i}\right. \\
C y_{i}\left(\alpha_{i}, \beta_{i}, M_{a i}\right. \\
C z_{i}\left(\alpha_{i}, \beta_{i}, M_{a i}\right.
\end{array}\right]+} \\
-\frac{1}{2} \rho S\left(V_{0 i}^{V}\right)^{2}\left[\begin{array}{ccc}
-\cos \alpha_{i}^{V} \cos \beta_{i}^{V} & -\cos \alpha_{i}^{V} \sin \beta_{i}^{V} & \sin \alpha_{i}^{V} \\
-\sin \beta_{i}^{V} & \cos \beta_{i}^{V} & 0 \\
-\sin \alpha_{i}^{V} \cos \beta_{i}^{V} & -\sin \alpha_{i}^{V} \sin \beta_{i}^{V} & -\cos \alpha_{i}^{V}
\end{array}\right]\left[\begin{array}{c}
C x_{i}\left(\alpha_{i}^{V}, \beta_{i}^{V}, M_{a i}^{V}\right) \\
C y_{i}\left(\alpha_{i}^{V}, \beta_{i}^{V}, M_{a i} V\right) \\
C z_{i}\left(\alpha_{i}^{V}, \beta_{i}^{V}, M_{a i}^{V}\right)
\end{array}\right]
\end{gathered}
$$


gdzie: $C x_{i}, C y_{i}, C z_{i}$ - odpowiednio bezwymiarowe współczynniki sił oporu, bocznej i nośnej dla $i$-tego przekroju skrzydła, $M_{a i}, M_{a i}^{V}$ - odpowiednio liczby Macha dla wypadkowej prędkości lotu $V_{0 i}$ i $V_{0 i}^{V}$ w $i$-tym przekroju skrzydła, $V_{0 i}$ - wypadkowa prędkość lotu w $i$-tym przekroju skrzydła, $V_{0 i}^{V}$ - wypadkowa prędkość (bez uwzględnienia przyrostu prędkości od prędkości kątowej) w $i$-tym przekroju skrzydła

$$
V_{0 i}^{2}=\left(U_{i}^{\prime}\right)^{2}+\left(V_{i}^{\prime}\right)^{2}+\left(W_{i}^{\prime}\right)^{2} \quad\left(V_{0 i}^{V}\right)^{2}=U_{i}^{2}+V_{i}^{2}+W_{i}^{2}
$$

\section{Założenia}

Do obliczeń został przyjęty model samolotu zbliżonego do Beechcraft 1900C, dla którego charakterystyki aerodynamiczne zostały wyznaczone w programie Panukl:

- $32 \mathrm{~m}$ - odległość podłużna samolotów w formacji (2 rozpiętości),

- $0 \mathrm{~m}$ - separacja pozioma oraz pionowa samolotów w formacji [9],

- $41 \mathrm{~m}$ - odległość usterzenia poziomego od skrzydła lidera.

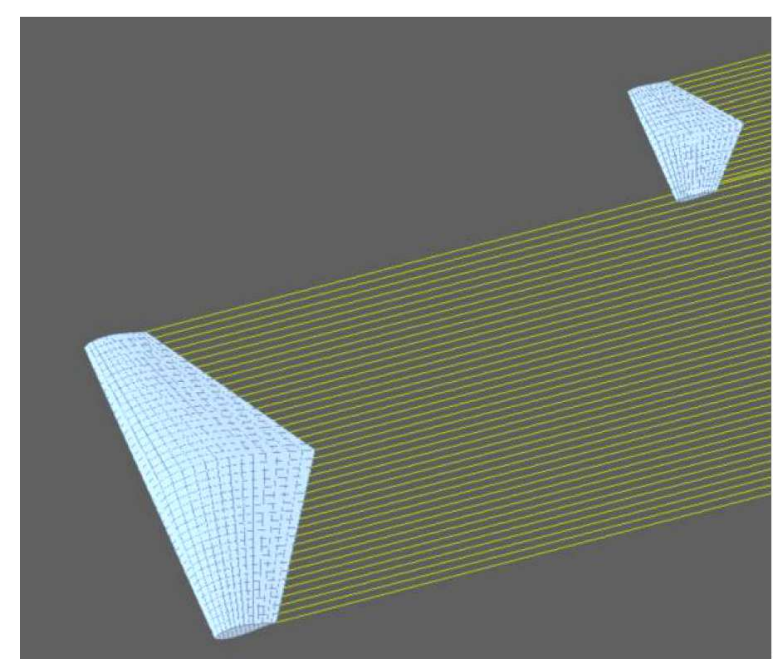

Rys. 10. Wizualizacja modelu w programie Panukl

Powyższe założenia dotyczące separacji samolotów spowodowały powstanie jedynie pionowej składowej prędkości indukowanej na samolocie skrzydłowym. Jej wartość jest największa na końcówce skrzydła i w pracy zostało przyjęte, że powoduje wystąpienie prędkości kątowej przechylania. Natomiast pozostałe składowe: pochylania oraz odchylania prędkości kątowej przyjmują wartość zerową.

Obliczenia wykonano przy wartościach:

- $P=0,012 \mathrm{rad} / \mathrm{s}$ - prędkość kątowa przechylania,

- $b=16 \mathrm{~m}$ - rozpiętość płata,

- $b_{p}=6 \mathrm{~m}$ - rozpiętość usterzenia poziomego,

- $S=31 \mathrm{~m}^{2}$ - powierzchnia płata,

- $m=10700 \mathrm{~kg}$ - masa samolotu,

- $\rho=0.863 \mathrm{~kg} / \mathrm{m}^{3}$ - gęstość powietrza dla $3500 \mathrm{~m}$,

- $U=125 \mathrm{~m} / \mathrm{s}$ - prędkość podłużna samolotu,

- $W, V=0 \mathrm{~m} / \mathrm{s}$ - prędkość wznoszenia oraz poprzeczna samolotu,

- $\varepsilon=0.1^{\circ}-$ kąt zwichrzenia geometrycznego.

Jedna połówka skrzydła została podzielona na 20 pasów, natomiast jedna część usterzenia poziomego na 10 pasów. 


\section{Wyniki}

Wyniki obliczeń wykonane dla skrzydła samolotu Beechcraft 1900C zostały przestawione na rysunkach 11-13. Są to rozkłady składowych siły aerodynamicznej na osie układu współrzędnych związanego z samolotem wzdłuż rozpiętości skrzydła.

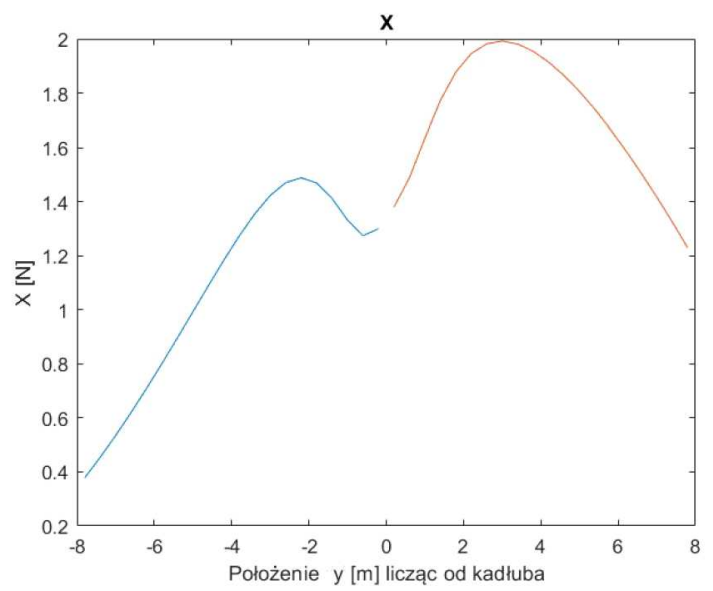

Rys. 11. Składowa $X$ obciążenia na skrzydłach

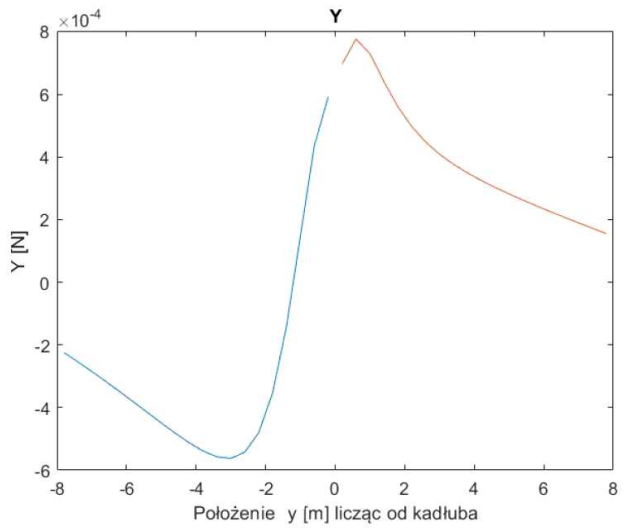

Rys. 12. Składowa $Y$ obciążenia na skrzydłach

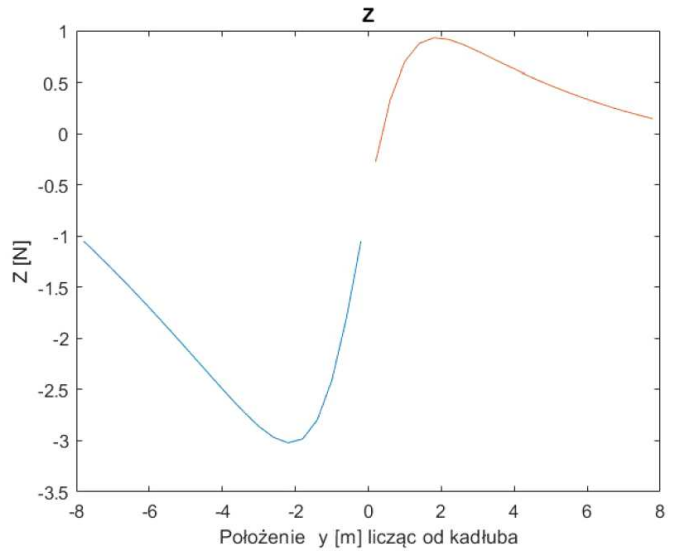

Rys. 13. Składowa $Z$ obciążenia na skrzydłach 
Wyniki obliczeń wykonane dla usterzenia poziomego samolotu Beechcraft 1900C zostały przestawione na rysunkach 14-16. Są to rozkłady składowych siły aerodynamicznej na osie układu współrzędnych związanego z samolotem wzdłuż rozpiętości usterzenia poziomego.

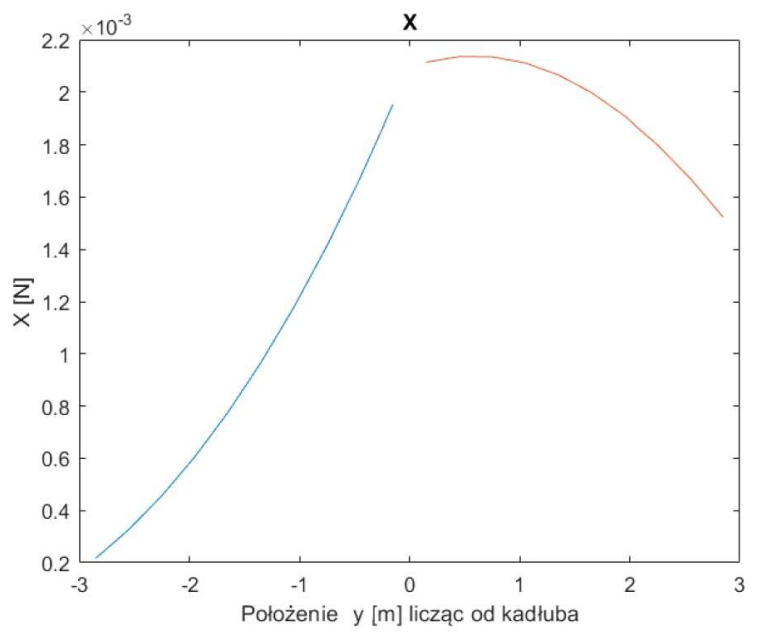

Rys. 14. Składowa $X$ obciążenia na usterzeniu poziomym

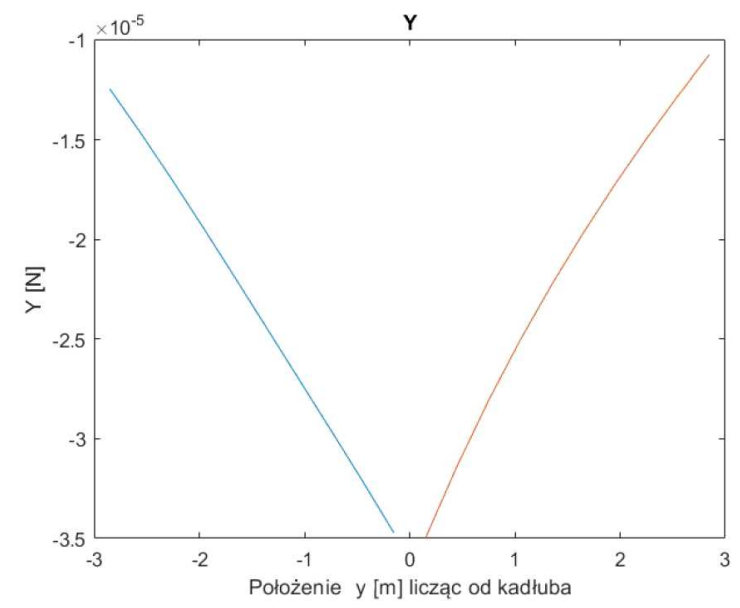

Rys. 15. Składowa $Y$ obciążenia na usterzeniu poziomym

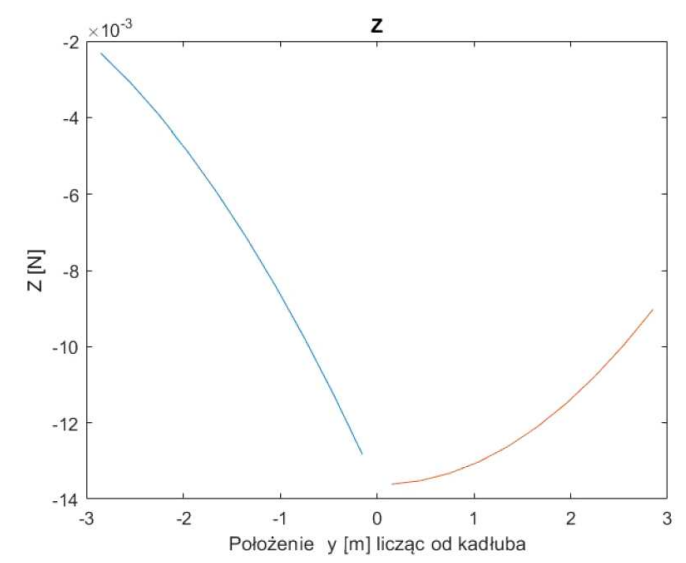

Rys. 16. Składowa $Z$ obciążenia na usterzeniu poziomym 
Przy zadziałaniu jedynie prędkości kątowej przechylania najistotniejszym do analizy otrzymanym rozkładem jest obciążenie w osi $Z$. Zwrot i zmiana znaku rozkładu po przejściu na drugie skrzydło pokazuje, że otrzymane wyniki można traktować jako poprawne.

Niskie wartości obciążeń na usterzeniu poziomym pokazują, że większa odległość od wiru we wszystkich trzech osiach zmniejsza wpływ jego działania aż kilkukrotnie w porównaniu do skrzydła.

\section{Podsumowanie}

W pracy zostało przedstawione zagadnienie dotyczące obliczeń obciążeń aerodynamicznych powstałych na samolocie skrzydłowym w wyniku lotu w formacji. Niskie wartości otrzymanych rozkładów obciążeń pozwalają stwierdzić, że wpływ prędkości kątowej powstałej w wyniku wiru jest nieznaczny i może być pomijalny przy założonych warunkach obliczeniowych. Wir generowany przez samolot lidera może być wykorzystany do zmniejszenia oporu aerodynamicznego samolotu skrzydłowego, a co za tym idzie zmniejszenia minimalnego ciągu niezbędnego do lotu, co prowadzi do oszczędności paliwowych. Komputery pokładowe samolotów lecących w formacji będą musiały same wyliczać optymalne położenie nie tylko ze względu na pozytywny wpływ wiru, ale również na szkodliwe obciążenia. Docelowo samoloty skrzydłowe będą miały zaprogramowane graniczne obciążenia, w których lot ustalony będzie mógł być przeprowadzony bezpiecznie.

Wykorzystana w pracy metoda pasowa nie wymaga dużych mocy obliczeniowych, co pozwala na wykorzystanie jej na pokładzie samolotu. Ze strony obciążeń aerodynamicznych dla samolotu tej klasy odległość dwóch rozpiętości skrzydeł jest separacją bezpieczną dla lotu w formacji. Natomiast w celu zastosowania lotu w formacji w codziennych operacjach należałoby jeszcze uwzględnić dodatkowe czynniki, m.in. czas reakcji autopilota na zaburzenia lotu samolotu lidera. Odległość 32 metrów o zadanej prędkości samolot pokonuje raptem w 0,25 sekundy. Z punktu widzenia bezpieczeństwa taka separacja byłaby niemożliwa do zastosowania.

\section{Bibliografia}

1. Mikosz S., Leci z nami pilot, Wydawnictwo G+J, 2011

2. Wypowiedź Prezesa LOT, https://finanse.wp.pl/mikosz-pierwszy-dreamliner-w-2012-r-6114632979900545a

3. ICAO, Flight Planning and Fuel Management Manual, 2012

4. Lissaman P.B.S., Shollenberger C.A., Formation flight of birds, Science, 168, 1003-1005, 1970

5. Portugal S.J., Hubel T.Y., Fritz J., Heese S., Trobe D., Voelkl B., Hailes S., Wilson A.M., Usherwood J.R., Upwash exploitation and downwash avoidance by flap phasing in ibis formation flight, Nature International Weekly Journal of Science, 505, 399-402, 2014

6. Bower G.C., Flanzer T.C., Krooy I.M., Formation geometries and route optimization for commercial formation flight, 27th AIAA Applied Aerodynamics Conference, USA, 2009

7. https://aviationweek.com/commercial-aviation/boeing-fedex-777f-tests-confirm-wake-fuel-burnbenefit, Aviationweek 10.12.2019

8. Raport finalny z katastrofy Learjet 45 z dnia 4 listopada 2008, Secretaria De Comunicaciones y Transportes, Meksyk, 2009

9. Antczak A., Sibilski K., Optimisation of aircraft position in the formation flight for the drag reduction, Journal of KONES Powertrain and Transport, 25, 3, 2018 
10. Houghton E.L., Carpenter P.W., Aerodynamics for Engineering Students, 5th Ed., Wielka Brytania, 2003

11. Lasek M., Pietrucha J., Sibilski K., ZŁocka M., Modelowanie i symulacja lotu mikrosamolotu ze skrzydłami machajaccymi, [W:] Mechanika w Lotnictwie, ML-X 2002, J. Maryniak (Red.), ZG PTMTS, Warszawa, 2002

12. Pyrz J., Modelowanie $i$ analiza dynamiki sterowanego samolotu w zakresie krytycznych katów natarcia, Praca doktorska, Politechnika Warszawska, 2000

\section{Use of the strip method during formation flight of a passenger aircraft}

In this paper, aerodynamic loads in a wing plane flying in V-formation were calculated by the strip method. At the beginning, the necessity of airlines for fuel savings was presented along with examples of methods of such savings. Then analysis of the application of formation flights for passenger aircraft was shown. Next, a mathematical model to determine the induced speed generated by the leader on the wingman was presented and the strip method for simulation of the aerodynamic loads was described. At the end, calculation assumptions and the results were presented. 